\title{
The Bakke Case and the Future of "Affirmative Action"
}

\author{
Richard A. Posner†
}

Allan Bakke twice applied for admission to the medical school of the University of California at Davis, a state university, and was twice rejected. The medical scliool had reserved sixteen of the liundred places in the entering class for economically or educationally disadvantaged imdividuals from four racial-ethnic groups: Negro, Asian, American Indian, and Chicano (Mexican-American). A disadvantaged applicant who was not a member of one of these four racial-ethnic groups was not eligible for the special admissions prograin. Although niembers of the designated racial-ethnic groups could also compete for the remaining eiglity-four places in the regular application process, within the special admissions program they were not evaluated in comparison with regular applicants but only in comparison witl each other. Average test scores and other measures of academic promise of those admitted under the special prograin were far below those of otlier entrants and of many rejected applicants, including Bakke.

Bakke sued the University of California, alleging that his exclusion from the entering class was the result of racial discrimination im violation of the equal protection clause of the fourteenth amendment, Title VI of the Civil Riglits Act of 1964, ${ }^{1}$ and the California Constitution. The California Supreine Court upheld Bakke's equal protection claim, holding that racial criteria could not be used to determine admission to a state educational institution. ${ }^{2}$ The court declined to consider his other grounds. The United States Supreme Court affirmed the judgment of the California Supreme Court insofar as it ordered Bakke admitted to the Davis medical school, but reversed the judginent insofar as it enjoined the University fronı taking any account of race in its admissions decisions. ${ }^{3}$

The Supreme Court was sharply divided. Justice Stevens, in an

$\dagger$ Lee and Brena Freeman Professor of Law, University of Chicago. Bernard Meltzer's helpful comments on an earlier draft are gratefully acknowledged.

1. Title VI forbids racial discrimination by recipients of federal financial assistance. 42 U.S.C. $\S 2000 d(1976)$.

2. Bakke v. Regents of the University of Cahfornia, 18 Cal. 3d 34, 553 P.2d 1152, 132 Cal. Rptr. 680 (1976), aff'd in part, rev'd in part, 98 S. Ct. 2733 (1978).

3. Regents of the University of California v. Bakke, 98 S. Ct. 2733 (1978). 
opinion concurred in by Chief Justice Burger and Justices Stewart and Rehnquist, voted to affirm the judgment of the California Supreme Court in its entirety on the ground that the use of race as a factor in selecting students for adinission to federally aided educational institutions violated Title VI of the Civil Rights Act; he did not reach the question whether it might also violate the fourteentli amendment. Justice Powell, who cast the fifth vote to affirm the judgment as to Bakke's admission, wrote that although umiversities can sometimes take race into account in admissions decisions, the type of program used by $\mathrm{Da}$ vis was impermissible. He based this conclusion on the fourteenth anendment because, unlike Justice Stevens, he viewed the standard of Title VI to be the same as the constitutional standard. Justices Brennan, White, Marshall, and Blackmun voted in a joint opinion to reverse the judgment of the California Supreme Court in its entirety. Justice Powell's fifth vote completed a majority for reversing the part of the judgment that enjoined the Uriversity from giving any consideration to race in its admissions decisions.

Thus, the Court appears to have divided evenly over the legality of reverse discrimination in school admissions, with Justice Powell casting the deciding vote. His opinion is therefore central to any attempt to predict the future course of the law relating to reverse discrimination and will be the focus of this Article. The slightest change in the composition of the Court could, of course, deprive Justice Powell's views of their present centrality.

The Bakke case received enornous attention while it was awaiting decision in the Umited States Supreme Court, largely because reverse discrimination, generally under the euphemistic name of "affirmative action," has become almost as deeply entrenched an institution im American life as was segregated public education in the South before the Brown decision. A decision broadly and unequivocally outlawing reverse discrimination would have exposed innumerable universities, corporations, labor umions, and other institutions to successful lawsuits for reverse discrimination. It would have outraged liberal opinion, the federal government's affirmative action bureaucracy, the leadership of a number of minority organizations, and other vocal and influential groups. And, according to a Gallup Poll, it would have pleased the vast inajority of the American people, including almost two-thirds of all nonwhites. ${ }^{4}$

The Court in Bakke did not outlaw reverse discrimination, but it cast a cloud over it. This was overlooked in the press comment on the decision and, I believe, deliberately suppressed by the supporters of affirnative action as they rushed into print with preemptive comments on

4. See N.Y. Times, May $1,1977, \S 1$, at 33 , col. 1 . 
the decision based on hasty and tendentious readings of the opinions. The Attorney General, the Assistant Attorney General for Civil Rights, and the Secretary of Health, Education and Welfare, among others, promptly characterized the decision as a vimdication of affirmative action. This characterization is inaccurate.

\section{I}

The equal protection clause of the fourteenth amendment forbids a state to deny any person the equal protection of the laws. Although the original purpose of the clause was to protect the newly emancipatcd Negro slave from discriminatory state action, it has long been used as a vehicle for reviewing state action that discriminates on grounds unrelated to such characteristics as race or national origin. Thus, legislation taxing railroads more heavily than other business firms is regularly challenged, and sometimes invahidated, under the equal protcction clause. The Supreme Court, unwilling to become enmeshed in detailed review of the fairness of state tax and regulatory laws, has generally upheld legislation in such areas whenever it can be shown that the alleged discrimination bears some rational relation to a constitutionally permissible state policy.

If this approach were applied to racial discrimination, however, it would blunt the central thrust of the equal protection clause, for a good deal of racially discriminatory state action could probably be justified under a broad "rationality" standard. ${ }^{5}$ For example, since blacks are disproportionately responsible for crimes of violence, it might be rational-in the generous sense of the term that the Court uses in economic cases-to require blacks, but not whites, to carry identification. Or, since the educational performance of blacks is on average below that of whites, it might be rational to segregate blacks im separate schools, just as second graders are "segregated" from third graders or bright children "segregated" froin dull children in schools that employ track systeins. Of course, powerful arguinents can be inade that such racially discriminatory measures would be excessive, that individualized treatment would be more appropriate, that the administrative convenience of racial classification would be outweighed by the social costs of stigmatizing certain individuals as deviant or inferior, that racially correlated behavioral differences are theinselves products of discrimination, and so forth. Yet none of these arguments is so overwhelming

5. As I have argued elsewhere, there is considerable support for the view that most racial discrimination today is motivated not by hatred or exploitativeness, but simply by the administrative cost savings obtainable by foregoing individualized assessment and generatizing from the average performance of a group to the likely performance of one of its members. See R. POSNER, Economic Analysis of Law 536-38 (2d ed. 1977); Posner, The DeFunis Case and the Constitutionality of Preferential Treatment of Racial Minorities, 1974 SuP. CT. Rev. 1. 
that it would carry the day under the relaxed rationality standard of review used in economic cases where the Court extends every indulgence to the state's justification for the challenged discrimination.

The fact that the kind of administrative cost savings which provide the "rational basis" to save most taxing classifications from being invalidated under the equal protection clause seem a paltry excuse for racial discrimmation may explain why the Court has subjected racial and ethnic discrimination to a "strict scrutiny" test. This test reverses the presumption of legahity attached to governmental action reviewed under the rationahty standard. In fact, it places a nearly insurmountable burden of proof on the state to justify discrimination.

A critical threshold issue in Bakke was whether discrimination against whites was to be tested under the rationality standard or under the strict scrutiny standard. Justice Powell, the "swimg" vote on the Court, decided that the latter was the correct standard, and his vehemence in rejectimg the claim that reverse discrimination should be judged by a more lenient standard than conventional discrimination may say much for the course of future reverse discrimination decisions. Solne quotations will bring out the flavor of the Powell opinion, a flavor that media reports on the Bakke decision have failed to convey.

Justice Powell first refused to accord constitutional significance to the distmction between "quotas" and "goals," observing that the Davis special admissions program involved "a purposeful, acknowledged use of racial criteria." $\mathrm{He}$ then declared: "The guarantee of equal protection cannot mean one thing when applied to one individual and something else when applied to a person of another color. If both are not accorded the same protection, then it is not equal."7 He rejected the argument that simce Bakke, as a white inale, was not a member of a "discrete and insular mmority" requiring special protection froin the majoritarian political process, the Davis special admissions program did not call for strict scrutmy. He concluded that "[r]acial and ethnic distinctions of any sort are inherently suspect and thus call for the most exacting judicial examination."8

Amplifymg this theme, Justice Powell poimted out that by the time the equal protection clause was revitalized as a shield for individual liberties in the late 1930s, "it was no longer possible to peg the guarantees of the Fourteenth Amendment to the struggle for equality of one racial minority [blacks]." 9 The nation "had become a nation of minorities," 10 each of which "had to struggle - and to some extent struggles

6. $98 \mathrm{~S}$. Ct. at 2748 n.27.

7. Id. at 2748.

8. Id. at 2749.

9. Id.

10. Id. 
still-to overcome the prejudices not of a monolithic majority, but of a majority composed of various minority groups." 11 Thus, although the original purpose of the fourteenth amendment was to protect blacks, " $[t]$ he clock of our liberties . . . cannot be turned back to 1868. It is far too late to argue that the guarantee of equal protection to all persons permits the recognition of special wards entitled to a degree of protection greater than that accorded others."12 Justice Powell's exposition of the "intractable . . . difficulties entailed in varying the level of judicial review according to a perceived 'preferred' status of a particular racial or ethnic minority" lies at the heart of his opinion, and deserves extended quotation:

The concepts of "majority" and "minority" necessarily reflect temporary arrangements and political judgments. As observed above, the white "majority" itself is composed of various minority groups, most of which can lay claim to a history of prior discrimination at the hands of the state and private individuals. . . . There is no principled basis for deciding which groups would merit "heightened judicial solicitude" and which would not. . . . The kind of variable sociological and political analysis necessary to produce such rankings simply does not lie within the judicial competence-even if they otherwise were politically feasible and socially desirable..$^{13}$

Justice Powell unhesitatingly rejected the view that discrimination against members of the white "majority" for a "benign" purpose is not suspect, and hence not subject to strict scrutiny:

[T] here are serious problems of justice connected with the idea of preference itself. First, it may not always be clear that a so-called preference is in fact benign. Courts may be asked to vahidate burdens imposed upon individual nembers of particular groups in order to advance the group's general interest. Nothing in the Constitution supports the notion that individuals may be asked to suffer otherwise impermissible burdens in order to enhance the societal standing of their

11. Id. at 2749-50 (footnotes omitted). In a footnote to the opinion Justice Powell adds: Members of various religious and ethnic groups, primarily but not exclusively of eastern, and middle and soutlerm European ancestry, such as Jews, Catholics, Italians, Greeks, and Slavic groups [continue] to be excluded from executive, middle-management and other job levels because of discrimination based upon their religion and/or national origin.

Id. at 2749 n.32 (quoting 41 CFR $\$ 60-50.1$ (b) (1977)).

12. Id. at 2751 (citations omitted). In a footnote Justice Powell quotes Professor Bickel on this point:

"The lesson of the great decisions of the Supreme Court and the lesson of contemporary history have been the saine for at least a generation; discrimination on the basis of race is illegal, immoral, unconstitutional, inherently wrong, and destructive of democratic society. Now this is to be unlearned and we are told that this is not a matter of fundanental principle but only a inatter of whose ox is gored. Those for whom racial equality was demanded are to be more equal than others. Having found support in the Constitution for equality, they now claim support for inequality under the same Constitution." $A$. Bickel, Tlie Morality of Consent 133 (1975).

Id. at 2751 n.35.

13. Id. at 2751-52 (footnotes omitted). 
ethnic groups. Second, preferential programs may only reinforce cominon stereotypes holding that certain groups are unable to achieve success without special protection based on a factor having no relationship to individual worth. Third, there is a ineasure of inequity in forcing innocent persons in respondent's position to bear the burdens of redressing grievances not of their making. ${ }^{14}$

Justice Powell's conclusion that reverse discrimination should be tested under a strict scrutiny standard finds support, as he notes, in the difficulty of distinguishing between "benign" and "invidious" discrimination, or between discrimination against a minority and discrinnination by a inajority against itself. Discrimination agamst Jews designed to limit their representation in high-visibility occupations such as law or journalisin could be defended as being in the Jews' "best interests," while discrimination in favor of Thurgood Marshall's son might appear quite invidious to a white male from an econornically or culturally disadvantaged background. Solne believe that affirmative action is the product of a coahition of "WASP" and Jewish intellectuals, black leaders, and iniddle-class wornen, all ganging up on "white ethnics" of lower middle-class background. The Gallup Poll results, referred to earlier, ${ }^{15}$ lend sonie plausibility to this conjecture. Sorting out these contentions and properly characterizing particular instances of reverse-or for that matter, direct-discrimination is hardly a task for a court. It invites the kind of fuzzy analysis that was once used to justify the separate but equal doctrine of Plessy v. Ferguson. ${ }^{16}$

The four groups snigled out for preferential treatment by the Davis nedical school are not the only groups that have been discriminated against in this country. Others that come to mind are Puerto Ricans, Jews, Catholics, Morınons, Irish, Italians, Poles, Scandinavians, Germans, Hungarians, and women. To be sure, many of these groups appear to have overcoine any handicaps imposed by discrimination, but the saine is true of the Asians accorded preference by the Davis medical school along with blacks, Mexican Ainericans, and American Indians. ${ }^{17}$ Justice Powell had good reason to conjure up the unedifying spectacle of minorities clamoring for judicial recognition as groups entitled to discriminatory preference. The logic of reverse discrimmation would seem to require that courts consider including at least some of these additional groups among those to be accorded preferential treatneent. But that inight well result in discrimmation by a coalition of minorities, constituting in the aggregate a clear majority, against a minority consisting of white Anglo-Saxon Protestants, or perhaps just of

14. Id. at $2752-53$ (citations omitted).

15. See note 4 and accompanying text supra.

16. 163 U.S. 537 (1896).

17. See text accompanying notes $39-40$ infra. 
the males $\mathrm{m}$ this group. Is the rule then to be that a public institution may keep addimg minorities to the honor roll until it approaches fifty percent of the population, and then arbitrarily retuse to accord any preference to other groups that have been discriminated against? It is to such absurdities that reverse discrimination seems to lead.

A second and related reason for subjecting reverse discrimination to the same strict scrutiny applied to discrimination of the old-fashioned sort-though not one stated by Justice Powell-is that both are based on the same kind of racial stereotyping. The essence of discrimination is the use of race or some similar trait as a proxy for individual characteristics to avoid the costs entailed in ineasuring these characteristics directly. ${ }^{18}$ Thus, if one's experience has been that the average black is, for whatever reason, a less desirable neighbor than the average white, one might quite rationally and not at all viciously prefer living in a neighborhood covered by racially restrictive covenants to living in a community in which sone neighborhood council or subdivision association tries to determme on a case-by-case basis the suitability of newconiers to the neighborhood. ${ }^{19}$ The refusal to exannine individual characteristics is, however, a source of both economic imjury and profound personal resentment to members of the excluded racial or ethnic groups, and I interpret the fourteenth amendment to forbid pubhic institutions to impose this kind of harm for the sake of administrative convenience.

Reverse discrimination likewise mvolves the use of race as a simple, convenient proxy for individual characteristics that may be costly to measure directly. For example, the Davis medical school thought that a black was more likely than a white of equally disadvantaged background to practice inedicine in a community underserved by doctors. If this generalization is correct (a debated issue), it is nonetheless just a shortcut for the inore elaborate and costly inquiry that would be necessary to determine whether an individual black was in fact inore likely to practice in such a community than a competing white applicant. The idea that blacks return to their communities to practice is a racial stereotype-a favorable one perliaps (like "Orientals are good at math"), but a racial stereotype nonetheless-and the fourteenth amendment would seem to forbid racial stereotyping even when it is used to confer a preference on nembers of some racial minority.

Although Justice Powell's opinion was the only one to state explicitly that reverse discrimmation is to be judged by the same standard as

18. See Phelps, The Statistical Theory of Racism and Sexism, 62 AM. ECON. REv. 659 (1972).

19. Or, for that matter, in a community that uses large-lot zoning to screen out the poor. 
discrimination against blacks and neinbers of other groups that have traditionally been the targets of discrimination, it seems hikely that this position would now command a majority of the Court. ${ }^{20}$ I cannot think of a case in inodern times in which racial discrimination has survived the Supreine Court's strict scrutiny, ${ }^{21}$ so if that is the standard to be applied, the future of reverse discrimination is bleak.

This impression is reinforced by the part of Powell's opinion in which he examined the inedical school's asserted reasons for its discriminatory admissions policy. Applying the strict scrutimy standard, under which "'a State must show that its purpose or interest is both constitutionally permissible and substantial, and that its use of the classification is "necessary . . . to the accoinplishment" of its purpose or the safe-guarding of its interest," "22 Justice Powell found that two of the inedical school's proffered reasons were insubstantial on their face, a third was based on an unproved factual premise, and the fourth, though potentially substantial, had been inplemented improperly.

The first reason offered by the inedical school in support of its special admissions program was the interest in "'reducing the historic deficit of traditionally disfavored mimorities in inedical schools and the inedical profession." "23 Justice Powell rejected out of hand this basis for the program: "Preferring meinbers of any group for no reason other than race or ethmic origin is discrimination for its own sake."24

He rejected the second reason-"countering the effects of societal discrimination"2s - for want of any judicial, legislative, or administrative findings of discrimination on which the medical school might have predicated a discriminatory admissions policy. ${ }^{26}$ This raises the question whether the Davis special admissions program would have withstood challenge if, prior to the time it was conceived and implemented, the California legislature had found that the medical school had discriminated unlawfully. The answer is shrouded in ambiguity, for although Justice Powell stated that the Davis medical school neither

20. This assumes, to be sure, that the four Justices who would have affirmed the California Supreme Court's judgment in its entirety would, had they not believed that a dispositive nonconstitutional ground was available to them, have joined at least in that part of Justice Powell's opinion that holds discrimination against whites to be subject to strict scrutiny.

21. Ironically, the last case in which the Court upheld a nonremedial racial classification, decided in 1944, was also the first case to hold that classifications based on race are suspect and therefore subject to strict scrutiny. See Korematsu v. United States, 323 U.S. 214 (1944). United Jewish Organizations, Inc. v. Carey, 430 U.S. 144 (1977) (upholding "racial gerrymandering" in favor of blacks) seeins a special case for reasons explamed in the opinions. See especially the concurring opinion of Justice Stewart, id. at 179-80.

22. $98 \mathrm{~S}$. Ct. at 2756-57 (quoting In re Griffiths, 413 U.S. 717, 722-23 (1973)).

23. Id. at 2757.

24. Id.

25. Id.

26. Id. at 2757-59. 
made nor was competent to make findings of past unlawful discrimination, he nowhere indicated which legislative and administrative bodies do have the authority to make such findings. ${ }^{27}$

If Justice Powell intended to recognize the authority of any legislative body or its delegate to identify and remedy unlawful discrimmation, this would create an enormous loophole in the constitutional principle he announced. Reverse discrimination might be predicated on a legislative finding of past discrimination through a two-stage process. In the first stage, the legislature would "find" that some group has been victimized by some institution, and im the second the legislature, or a delegate of it such as the Davis medical school, would adopt a policy of reverse discrimmation as a "remedy." Since legislative factfindings are essentially unreviewable in court, a legislature that wanted to practice or authorize reverse discrimination could subject institutions to ostensibly "remedial" action by makmg conclusory findings of culpable discrimination on their part without any basis in probative evidence.

But the better guess is that no such loophole was intended, for Justice Powell must have realized that a constitutional principle which any legislative body is free to disregard by an empty recital of "fact" is not a constitutional principle worthy of the name. ${ }^{28}$ In acknowledging that remedial ineasures employing racial classifications may be based on a legislative or administrative finding of unlawful discrimination, Justice Powell was probably referring to the express powers of Congress under section 5 of the fourteenth amendment and section 2 of the fifteentli amendment to implement the substantive prohibitions of those amendments-powers which have no counterpart for state legislatures. Thus, although Congress and its delegates may have the authority to identify instances of unlawful discrimination and adopt a

27. Reverse discrimmation is an accepted remedy against an employer or imstitution that has been found guilty in an adjudicatory proceeding of unlawful discrimination. Although this remedy is somewhat dubious in that its brunt is often borne by innocent parties, see Posner, The DeFunis Case and the Constitutionality of Preferential Treatment of Racial Minorities, 1974 SuP. CT. REv. 1, 16, its justification is that an equity court must have broad discretion to fashion a decree that will effectively prevent the perpetuation of a wrong.

28. Justice Brennan, in a footnote to his opinion, interpreted Justice Powell's opinion to sanction a diseriminatory policy based on any legislative body's findings of past unlawful discrimination. See $98 \mathrm{~S}$. Ct. at 2787-88 n.42. Because the University of California's Board of Regents is itself a quasi-legislative body with the power to set university policy, under Justice Brennan's reading of Powell's opimion the special admissions program at Davis would have been invulnerable to attack if predicated on the Regents' findings of constitutional or statutory violations by the medical school. Justice Brennan thus criticized as "form over substance" Justice Powell's insistence that a legislative, adinmistrative, or adjudicatory finding of past discrimination precede the adoption of a remedial measure embodying racial classifications. Id. Yet Justice Brennan's description of the ease with which a legislative body could lay the foundation for the promulgation of a "remedial" discriminatory pohcy, see id., remforces, rather than negates, my reading of Justice Powell's opinion on this point. 
discriminatory policy as a remedy, ${ }^{29}$ all other legislative bodies (and $a$ fortiori their delegates) possess no such power. ${ }^{30}$

The third reason offered by the Davis inedical school for its discriminatory adinissions program was the state interest in "increasing the number of physicians who will practice in communities currently underserved." ${ }^{31}$ Justice Powell sunmarily rejected this reason for want of any evidence that Davis's special treatinent of preferred groups furthered this state interest. ${ }^{32}$

Justice Powell took a more kindly view of Davis's fourth asserted justification-that its special adinissions program furthered its interest im "the traditional benefits that flow from an ethnically diverse student body." 33 He began with the premise that the school's quest for a diverse student body is a compelling interest, reasonimg that "[a]cademic freedom, though not a specifically enumerated constitutional right, long has been viewed as a special concern of the First Amendment," and a university's academic freedom "imcludes the selection of its student body." 34 Because interaction annong students of diverse backgrounds may contribute in important ways to the education of both graduate and undergraduate students, and because racial and ethnic diversity is one aspect of diversity of backgrounds, Justice Powell concluded that it is permissible for a medical school to take race and ethnic origin mto account in the selection of its students.

29. But see Oregon v. Mitchell, 400 U.S. 112, 296 (1970) (Stewart, J., concurring in part and dissenting in part) (although Congress may have the authority to remedy violations of the equal protection clause, it does not have the power "to determine as a matter of substantive constitutional law what situations fall within the ambit of the clause, and what state interests are "compelling" ").

As to the scope of Congress' power under $\S 5$ of the fourteenth amendment to remedy unlawful discrimination, see Katzenbach v. Morgan, 384 U.S. 641 , 651 n.10 (1966), where the Court stated:

[Section 5 of the fourteenth amendment] does not grant Congress power . . . to enact

"statutes so as in effect to dilute the equal protection and due process decisions of this

Court." We emphasize that Congress' power under $\S 5$ is limited to adopting measures

to enforce the guarantees of the Amendment; $\S 5$ grants Congress no power to restrict,

abrogate, or dilute these guarantees.

Thus, even if Congress were to conclude that public universities had unlawfully discriminated against certam minorities in the past, it might not have the power to enact "remedial" legislation requiring the offending schools to reserve a fixed number of spaces for members of these groups. Such a law would abrogate the guarantees of the fourteenth amendment as interpreted in Justice Powell's holding that the equal protcction clause forbids the use of racial and ethnic quotas in the admissions process.

30. Of course as a practical inatter no legislature, including Congress, is likely to endorse the principle of reverse discrimination in the present political climate. This is the realpolitik theory of Justice Stevens' opimion: place the decision on statutory grounds such as Title VI, and the constitutionality of reverse discrimination need never be determined because no legislature will expressly enact a reverse discrimination law.

31. $98 \mathrm{~S}$. Ct. at 2757.

32. Id. at 2759-60.

33. Id. at 2757.

34. Id. at 2760. 
Were this conclusion not qualified later in the opinion, it would have to be regarded as reflecting, however dimly, racial stereotyping. It is never race or ethnic origin per se that provides the educationally relevant diversity, any inore than it is albinism. Some blacks, Chicanos, Asians, and American Indians are indistinguishable from their white peers aside froin purely physical features that are often no inore pronounced than those that distinguish whites of different national origins. A hight-skinned black of upper middle-class background inay reseinble a Southern European more than the latter resembles a Swede; nore inportant, he may have experiences, values, aspirations, tastes, speech, and manners that are substantially the same as those of his white peers. While many meinbers of some minority groups retain pronounced cultural differences that might distinguish them from nonminority students, others do not, and the latter contribute to the diversity of a student body only in a purely raciahist sense. To be sure, being black remains a good proxy for being culturally distinct. ${ }^{35}$ It is only recently that large-scale assimilation of blacks to the dominant culture has occurred, and the process is incomplete. But it is still just a proxy, and the use of racial proxies is, as I have suggested, the core of what is offensive in discrimination of the old-fashioned sort.

While accepting racial and ethnic diversity as a permissible factor in student selection, Justice Powell rejected, as an unnecessarily and hence impermissibly discriminatory method of proinoting such diversity, the Davis medical school's practice of reserving a fixed number of places in the entering class for inembers of particular racial or ethnic groups. This approach, he thought, gave excessive weight to the racial or ethnic factor in the overall quest for diversity. It is constitutionally permissible to use race or ethnic origin as one factor in the admissions decision, but not as the only factor:

The file of a particular black applicant may be examined for his potential contribution to diversity without the factor of race being decisive when compared, for example, with that of an applicant identified as an Italian-American if the latter is thought to exhibit qualities more likely to promote beneficial educational pluralism. Such qualities could include exceptional personal talents, unique work or service experience, leadership potential, maturity, demonstrated compassion, a history of overcoming.disadvantage, ability to commumicate with the poor, or other qualifications deemed important. In short, an admissions program operated in this way is flexible enough to consider all pertinent elements of diversity in light of the particular qualifications of each applicant, and to place them on the same footing for consideration, although not necessarily according then the same weight. ${ }^{36}$

35. Being of Asian descent, much less so. See text following note 45 infra.

36. $98 \mathrm{~S}$. Ct. at $2762-63$. 
It is possible to read this language in a way that attenuates the racialist character of allowing race per se to be considered an aspect of meaningful diversity. Justice Powell is perhaps saying that a university may use race to create a rebuttable presumption that an applicant has a contribution to make to a diverse student body, but it may not create an irrebuttable presumption. It may not refuse to weigh, in competition with the black applicant's claim to enhance diversity, the claim of a white to contribute greater diversity. For example, if a university were to prefer a hight-skinned, upper-income, thoroughly middle-class black over an academically more promismg white from a poor Appalachian family simply because the former was black, it would, under this reading of Justice Powell's opmion, be guilty of unlawful discrimmation.

I am not certain that this is the meaning Justice Powell intended, but my mterpretation is bolstered by his use of the term "competitive consideration of race and ethnic origm." 37 This usage implies that a diversity claim based purely on race or ethnic origm must always be open to challenge by a white who claims to have more to contribute to the genume, as distmct from purely racial and ethnic, diversity of the class. Tlius, Justice Powell approvingly quoted-and included as an appendix to his opinion-the policy of Harvard College, which declares: "A farm boy from Idaho can bring something to Harvard College that a Bostoman caimot offer. Similarly, a black student can usually bring something that a white person cannot offer."38 Usually, but not always. Were Harvard a public imstitution, a farm boy who was turned down in favor of an academically mferior Boston Brahmin who happened to be black would have a good claim that his constitutional rights had been violated.

If my interpretation of Justice Powell's opinion is correct, the dispensation it grants for the practice of reverse discrimmation is a very limited one. It amounts to allowing a university to create a rebuttable presumption that members of particular racial or ethnic groups are, by virtue of their race or ethnicity, likely to contribute an element of meaningful diversity to the student body. This is far froin the ringing affirmation of affirmative action that some of the media and governmental commentators discerned im Powell's opinion. And, significantly, Justice Powell's opmion nowhere endorses the decision of the

37. Id. at 2764.

38. Id. at $2762 \& 2765$ (emphasis added). Justice Powell's analysis does not justify the cynical comment that Davis's mistake was to reserve a fixed number of spaces for designated minorities, rather than to attempt to conceal its racial quota under a blanket of reassuring rhetoric in the style of Harvard College. Justice Powell made clear that an excluded white applicant to Harvard would have the same constitutional claim as Bakke if pretrial discovery or other investigation revealed that Harvard, while pretending to treat race and ethnic origin merely as one diversity factor to be weighed against others, was actually inplementing a scheme similar to that of Davis. See id. at 2763. 
Davis medical school to accord favored status to those minorities which, by a strange comcidence, happen to have political influence im the community. According to statistics in Justice Powell's opinion, of the eighty-four students admitted to the Davis medical school under the regular admissions program in 1973 and 1974, an average of nime were Asian. ${ }^{39}$ This is more than ten percent. Yet Asians comprise less than three percent of the population of California. ${ }^{40}$ Davis's special admissions prograin thus smgled out for preferential treatment a group that was already "overrepresented" in the student body. Since Asians, like Jews, are disproportionately affluent and well educated, I assume that they, like Jews, exercise a political influence disproportionate to their numbers in states such as California where they are heavily concentrated. I conjecture, then, that Asians were included in Davis's special admissions program as the political price for according preferential treatment to minorities underrepresented in the general admissions prograin. Under Justice Powell's opinion, a umversity is not permitted to assemble a list of favored minority groups without regard to their cultural distmctness and underrepresentation in the school. I doubt the City University of New York could try to make a preferential admissions policy pohtically attractive by designating Jews as a preferred group along with blacks and Puerto Ricans.

\section{III}

A few observations about the other opinions are im order. The opinion of Justices Brennan, White, Marshall, and Blackmun begins by characterizing the "central meaning" of the Bakke opinions as follows: "Government unay take race into account when it acts not to demean or insult any racial group, but to remedy disadvantages cast on minorities by past racial prejudice, at least when appropriate findimgs have been made by judicial, legislative, or administrative bodies with competence to act in this area." ${ }^{41}$ It is true that all of the Justices apparently believe that race can be taken imto account when necessary to remedy the effects of past unlawful discrimination - that is, as part of a remedy against a wrongdoer. A mere legislative declaration that some minority lias been hurt by prejudice may conceivably (though improbably) be an adequate predicate for reverse discrimination for five of the Justices, depending on how one reads Justice Powell's opinion on this point; ${ }^{42}$ but there is no evidence that this is the view of Justice Stevens or of the three Justices who joimed his opimion. In any event, simce the Bakke case did not mvolve a remedy against a wrongdoer, it is surprising that

39. Computed from id. at 2841 n.6.

40. Brief for the United States as Amicus Curiae at 4 n.3. See also id. at $46-47$ n.51.

41. $98 \mathrm{~S}$. Ct. at 2766.

42. See text accompanying notes 25-30 supra. 
the scattered remarks on remedial discrimination should be regarded as the "central meaning" of the Bakke opinions.

The next part of the Brennan group's opinion addresses the question of whether Title VI of the Civil Rights Act of 1964 provides an independent prohibition agamst reverse discrimination apart from the requirements of the Constitution, as Justice Stevens contended in his opinion. The Brennan group concluded that Title VI does not independently prohibit reverse discrimination. Indeed, there is little evidence in the legislative history of Title VI that Congress thought it was banning attempts to promote the interest of blacks and other minority group members by such methods as the Davis medical school employed. Congress probably thought it was simply extending the constitutional prohibition of discrimination to federally aided institutions and creating a new sanction of withholding federal funds to discourage such discrimination. On that reading, if reverse discrimination is unconstitutional, it would also violate Title VI. But Justice Stevens could not have taken that approach without reaching the constitutional question, which he declined to do. In a separate opinion, Justice White voiced strong practical objections to reading into Title VI a Congressional intention to create private remedies. Allowing a private cause of action for violations of Title VI raises the spectre of rejected applicants suing private universities receiving federal grants, logically seeking not adinission but rather the express Title VI sanction of a cut-off of federal funds. It is unlikely that Congress contemplated such a remedial scheine.

Having disposed of Title VI, the Brennan group turned to the constitutional question. The group agreed with Justice Powell that mere rationality was too liberal a standard for testing reverse discrimination. On the other liand, they considered strict scrutiny too stringent a standard, and thus proposed an intermediate test: "[to justify] racial classifications established for ostensibly benign purposes . . . an important and articulated purpose for [their] use inust be shown . . . [and] any statute inust be stricken that stigmatizes any group or that simgles out tliose least well represented in the pohtical process to bear the brunt of a benign purpose." 43

Even if, as I doubt, constitutional adjudication has room for an intermediate standard between rationality and strict scrutiny, the Brennan group's proposed standard is unworkable for the reason stated by Justice Powell-the concepts of "stigma" and "least well represented in the political process" cannot be given concrete ineaning in the litigation process. ${ }^{44}$ Moreover, the intermediate standard is dangerously lax with

43. $98 \mathrm{~S}$. Ct. at 2785 .

44. See id. at 2751 n.34. 
regard to discrimination of the old-fashioned sort. It will be recalled that such discrimination is tested under the standard of strict scrutiny, a test it invariably flunks. Under the Brennan group's approach, however, if the racial classification is one "established for ostensibly benign purposes," that fact alone takes it out of the strict scrutiny category and subjects it to the more permissive intermediate standard. Consequently, all a racist legislature would have to do to avoid strict scrutiny would be to recite that it was putting blacks in separate schools for their own good-an "ostensibly berign" purpose.

I turn now to two curious aspects of both the Brennan group opinion and Justice Marshall's separate opinion. The first is an evident ennbarrassment with Davis's inclusion of Asians among the preferred minority groups. ${ }^{45}$ All of the discussion in the Brennan group's opinion is of blacks and Chicanos, and all of the discussion in Justice Marshall's opinion is of blacks. One reason the Brennan group thought the Davis program constitutional was that the percentage of places reserved for the favored minorities, sixteen percent, was less than the percentage of the favored minorities in the California population, twentytwo percent. But twenty-two percent is the sum of only the blacks and Chicanos; no statistics are presented in any of the opinions regarding Asians. It is one thing to argue for preferential treatment of racial or ethnic groups that have in some sense "underachieved" and quite another to include, presumably in order to make the scheme of preferential treatnient politically palatable, another minority that has been very successful without the benefit of preferential treatment.

Had the Brennan group and Justice Marshall addressed the anounaly of including Asians in the special admissions program, they might have been led to reconsider a fundamental though unstated premise of their opinions-that but for discrimination, the percentage of black doctors would be approximately equal to the percentage of blacks in the population as a whole. This premise underlay the conclusion that Davis's special admissions program was justifiable by the same sort of logic that allows the use of a racial quota in a decrce seeking to remedy past discrimination-that is, as an attempt to undo the consequences of discrimmation. But once it is recognized that some minority group members are "overrepresented" in the medical profession, the premise that blacks would not be underrepresented but for discrimination is undermined. By the iron logic of arithmetic, it is impossible for every group to achieve proportionate representation in a profession where some groups are overrepresented for reasons unrelated to discrimination in their favor. Some other group or groups will have to be under-

45. Although American Indians were also included, there is no evidence that any American Indian was ever admitted to the medical school at Davis under the special admissions program. None of the opinions discusses this omission. 
represented to balance the statistics. Blacks may be one such group. Evidently Asian Americans have some special aptitude for or imterest in inedicine; why else are they overrepresented in the entering class of the Davis medical school? This suggests that medical aptitude or interest is not evenly distributed among racial and ethnic groups. Furthermore, if a group with a history of being discriminated agamst in this country, such as Asian Americans, has been able nonetheless to achieve disproportionately strong representation in the inedical profession, the failure of blacks to achieve proportionate representation cannot automatically be ascribed to the history of discrimination against them. Consequently it is preinature to conclude that the underrepresentation of blacks among those entering Davis through the regular adinissions process is the product of past discrimination against blacks. It could be an unrelated phenomenon.

A second puzzle in the Brennan group and Marshall opinions is the absence of any reference to McDonald v. Santa Fe Trail Transportation Co., ${ }^{46}$ decided by the Supreme Court just two terns before Bakke. The Court, in an opinion written by Justice Marshall, held that discrimination agamst a white person violated both Title VII of the Civil Rights Act of 1964, ${ }^{47}$ which forbids discrimination in employinent, and section 1981 of Title $42,{ }^{48}$ one of the Reconstruction civil rights statutes. The case involved two white employees and one black employee who were found to have engaged in the same misconduct; of the three, only the whites were fired. Justice Marshall had no difficulty in concluding that these statutes forbid discrimination agamst whites in favor of a black, despite the lack of any clear legislative history in support of such a result and despite seemingly contrary language in section 1981 itself. That section provides that all persons shall have the same right to inake contracts as is "enjoyed by white citizens," thus exphicitly stating that white persons are the standard and not the protected class. In McDonald, Justice Marshall regarded racial discrimination as the same thing whether directed against whites or against blacks. Although that decision was based on statutes other than Title VI, there was, as with Title VI, no evidence of a legislative intent to enact a standard of discrimination different from the constitutional standard. Equating reverse discrimination with old-fashioned discrimination is therefore not the novelty that the Brennan and Marshall opinions in Bakke inply.

It reinains to take brief note of Justice Blackmun's opinion. He joined the Brennan opinion, and why he felt called upon to add, as he put it, "additional components on the edges of the central question"49

46. 427 U.S. 273 (1976).

47. 42 U.S.C. $\$ 82000$ e to $2000 \mathrm{e}-17$ (1976).

48. 42 U.S.C. $\$ 1981$ (1976).

49. $98 \mathrm{~S}$. Ct. at 2808. 
escapes me. Essentially, Justice Blackmun restates the Brennan group opinion as a string of truisms. ${ }^{50}$ The central message of the opimion seems to be that since universities have long been known to discriminate in admissions on various grounds unrelated to academic merit (such as athletic prowess), why get upset over a little racial discrimination? ${ }^{\text {s1 }}$

\section{IV}

I want to conclude with some brief speculations on the future of affirmative action in hight of the Bakke decision. Affirmative action refers to efforts to rectify the continuing effects of past discrimination, as distinct from simply ceasing to discriminate. The Davis medical school's special adınissions program was a species of affirmative action. Certain features made it especially vulnerable to attack, psychologically if not legally. First, since people feel a natural anxiety about the qualifications of the doctors who treat them, the idea of an "affirmative action" doctor is particularly troubling. True, the students adinitted under the special program had, in theory, to meet the same academic standards for graduation as the regular entrants. But at least some universities will, if necessary, bend their standards to assure that not too many of their special students flunk out. Second, the Davis program mysteriously included among their preferred minorities Asian-Americans, although this group was patently not in need of preferential treatment vis-à-vis whites. Third, Davis refused to accord any special consideration to disadvantaged whites, thus failing to acknowledge that some whites might be as badly disadvantaged and deserving of a break in the adinissions process as a member of one of the preferred minority groups. Fourth, and related, the setting aside of a fixed number of places for the chosen minorities could not fail to trigger memories of the quotas so long used in American higher education to limit the numbers of Jews and Catholics admitted to the élite schools.

Supporters of affirmative action might hope that future decisions

50. Some examples will illustrate this point: "The sooner we get down the road toward accepting and being a part of the real world, and not shutting it out and away from us, the sooner will these difficulties vanish from the scene." $I d$. "In order to get beyond racism, we must first take account of race. There is no other way. And in order to treat some persons equally, we must treat them differently. We cannot-we dare not-let the Equal Protection Clause perpetrate racial supremacy." Id. "Today, again, we are expounding a Constitution. The same principles that governed $M^{\prime}$ 'Culloch's case in I819 govern Bakke's case in 1978. There can be no other answer." Id. at 2809.

51. It is somewhat ironic to have us so deeply disturbed over a program where race is an element of consciousness, and yet to be aware of the fact, as we are, that institutions of higher learning, albeit more on the undergraduate than the graduate level, have given conceded preferences up to a point to those possessed of athletic skills, to the children of alumni, to the affiuent who may bestow their largess on the institutions, and to those having connections with celebrities, the famous, and the powerful.

Id. at 2807 . 
will limit the Bakke holding to these rather special facts. I, however, am inclined to think otherwise. Although the facts of Bakke conceivably inay have influenced the decision, a majority of the Court probably now feels committed to strict scrutimy of reverse discrimination. ${ }^{52}$ It therefore becomes important to dctermine to what extent various forms of affirmative action fall within the category of policies subject to strict scrutiny.

It is relatively unlikely that the Bakke decision will be applied to "remedial affirmative action" following a judicial determination of unlawful discrimination. This form of affirmative action constitutes an accepted judicial practice which can be justified in inany cases as an exercise of the traditional discretion of an equity court. Conceivably, however, Justice Powell's apparent hostility toward reverse discrimmation might lead him, and perhaps other Justices, to scrutmize decrees embodying schemes of reverse discrimination with greater care in the future.

At the other end of the spectrum from the overt quotas often found in remedial decrees is the practice of simply searching harder for black applicants, whether for school adimission or for employment, than for white ones. Strictly speaking, this is racial discrimination; and outside the area of scliool admissions (where, in Justice Powell's view at least, the interest in diversity enjoys almost constitutional status) this type of affirmative action might well fail a test of strict scrutiny. But even in thc employinent context it seems unlikely that affirmative action consisting of no more than an "unequal search" will be held unconstitutional. Its adverse effects on whitcs are probably too slight and attenuated to constitute a denial of equal protection. I reach the same conclusion, for shightly different reasons, with regard to the practice anong some universities of giving larger scholarships to blacks than to equally needy whites. This is discrimination, but it is ancillary to lawful discrimination, since in pursuing the lawful goal of achieving student body diversity universities will sometimes have to compete financially for a limited pool of qualified minority apphicants.

The intermediate case is that of preferential treatment in employinent (including academic employınent). In many universities a slightly less qualified black may be hired in dehberate preference to a slightly more qualified white, and the same practice exists in many business and law firms and other nonacademic imstitutions. This is racial discrimination, and under Justice Powell's view it is subject to strict scrutiny. But the interests that Powell found sufficient to justify discrimination in favor of blacks in the college admissions process do not apply to employment. A manufacturer of aircraft has no interest in

52. See note 20 supra. 
having a racially divcrsified board of directors-none that I would take seriously, in any event-nor does a university have an interest in having a racially diversified faculty in its graduate accounting departnient. One can of course assert an interest in providing "role niodels" for black students (or in the industrial exanple, for black workers), but this involves the kind of facile psychologizing that Justice Powell rejected out of hand in responding to Davis' argument that black doctors are more likely than white doctors to practice in niedically underserved communities. Powell found no evidence to support the assertion that increasing the proportion of blacks in inedical school would help solve the problem, if indeed the problein exists. The "role model" argument suffers from the saine lack of concrete evidence.

The cutting edge of affirmative action is not college or university admissions; it is einployment. This is where a strict scrutiny standard, consistently and honestly applied, could profoundly affect existing government policy. Although HEW and other government enforcers tend to abjure the use of terms such as "quota" and instead describe affirmative action in terms of "search," "best efforts," "targets," and "goals," the effect of HEW's practices is to induce many universities and other einployers to discriminate in favor of members of the favored groups (blacks, women, or whomever). Meinbers of these groups are hired in preference to better-qualified white males because that is the easiest way to get the government off the employer's back. This is discrimination, and whcre the einployer is a public institution the victim of the discrimination has, under the logic of Justice Powell's opinion, a powerful constitutional case for rehef. The einployee's rights depend in the first instance on whether the prohibition against discrimination in Title VII is interpreted to be coextensive with the constitutional standards announced in Justice Powell's opinion. The McDonald decision in1plies that it will be so construed. Thus the logic of the Bakke case inay render illegal governmental efforts to inipose affirmativc action in the job market. 
